\title{
The Relief of Higher Education Loan through Islamic Waqf Bank
}

\author{
Muhammad Ridhwan Ab. Aziz ${ }^{1}$, Mohd Asyraf Yusof ${ }^{1}$, Fuadah Johari ${ }^{1}$, Asharaf Ramli ${ }^{1} \&$ Hisham Sabri ${ }^{1}$ \\ ${ }^{1}$ Faculty of Economics and Muamalat, Universiti Sains Islam Malaysia (USIM), Nilai, Malaysia \\ Correspondence: Muhammad Ridhwan Ab. Aziz, Faculty of Economics and Muamalat, Universiti Sains Islam \\ Malaysia, Nilai, Malaysia. Tel: 60-6-798-6410. E-mail: ridhwan.aziz@usim.edu.my
}

Received: July 6, 2014 Accepted: August 29, 2014 Online Published: October 30, 2014

doi:10.5539/ass.v10n22p175 URL: http://dx.doi.org/10.5539/ass.v10n22p175

\begin{abstract}
Islamic waqf bank is a special designed financial institution in Islam. This bank will benefit the students and also their parents, due to its unique structure that could finance student's education in term of fees and cost of living. Islamic waqf bank use the concept of cash waqf in terms of funding the education. The gifted capital or cash waqf was "transferred" to borrowers for certain period, which was then spent for all sorts of pious and social purposes inclusive for the investment objectives. It is recognized that there is no ample study in the area of cash waqf especially for managing Islamic waqf bank institution. Therefore, the study for managing cash waqf fund through Islamic waqf bank is essential in order for the fund to be use efficiently. The objective of this article is to explore the relief of higher education loan through Islamic waqf bank.
\end{abstract}

Keywords: waqf, Islamic waqf bank, cash waqf

\section{Introduction}

\subsection{Introduction to Waqf}

Waqf which (pl. Awqaf) is called Boniyad in Iran and Habs (pl. Ahbas) in North and West Africa. However, by taking its different meanings into consideration, waqf can be applied to non-perishable property whose benefit is extracted without consuming the property itself. Although waqf is not specifically mentioned in the Holy Quran, the concept of wealth distribution is strongly emphasized therein (Chowdhury et al., 2011). In fact, in the Quran, there are many verses which discuss and encourage Muslims to donate and give charity such as in Surah al-Baqarah (2: 261), al-Baqarah (2: 271), Ali Imran (3: 92), Ali Imran (3: 134), al-Lail (92: 18-21) and al-Hadid (57: 18) (Aziz, 2012).

From Shariah point of view, waqf may be defined as holding a mal (an asset) and preventing its consumption for the purpose of repeatedly extracting its usufruct for the benefit of an objective representing righteousness or philanthropy. This definition also covers several new forms of waqf that were not discussed in the classical literatures, such as the waqf of financial rights and waqf of usufruct (Kahf, 1998). The contemporary jurists also justify the validity of the cash waqf, because it is in the interest of the waqif (the donor), its beneficiaries and the society (Tahir, 2011). In addition, waqf assets can also be immoveable or moveable. In cash waqf, al-Waqif (donor) endowed cash instead of real estate. Cash waqf begin in primeval Mesopotamia, Greece and the Roman Empire. In fact, in the eighth century, Imam Zufar had approved cash waqf in the Islamic World for the first time. According to him, cash waqf would be invested through Mudarabah and profits would be spent for charity. Nevertheless, cash waqf did not expand and mature until the 16th century and after that century; it became popular, especially among the Ottomans. Many Muslims did not get chance to participate in waqf endowment because there is a wrong perception among Muslims that there may be waqf endowment through only land not in cash. They believed that land can fulfill the three conditions of waqf such as perpetuity, irrevocability and inalienability. However, land may be subject to demolition, destruction due to the natural calamity and waqf will only last till its value exist (Mohammad, 2008). Through proper cash waqf management, it is easily possible to hold waqf value as well as value enhancement. As a result, those who do not have land can participate in endowment through cash waqf. Nowadays, people have more choices for waqf by including cash into waqf.

Furthermore, cash waqf is far more important since it is more productive compared to land, buildings, books, cattle and so on, as it is testified by the existing research studies and have been found profitable in the practices of modern Islamic financial system (Chowdhury et al., 2011). 


\subsection{Higher Education Funding Issues in Malaysia}

The sustainability issue of the government fund to maintain higher education expenditure has been greatly debated in Malaysia especially in the post-period of Asian economic crisis that occurred in the late nineties. Malaysia's economy was greatly affected by the crisis which resulted in twin deficits of annual budget and huge depreciation of the currency that forced the authority to reduce public sector spending including higher education (Foong, 2005; Wilkinson \& Yusof, 2005). Prior to the crisis, the provision of higher education totally relied on public fund for the establishment and maintenance of operational cost of public universities as well allocation of financial aid to the students (Ahmat, 1987).

The policy of public fund spending for Malaysian higher education sector can be traced back to the establishment of New Economic Policy (NEP) launched in the $2^{\text {nd }}$ Malaysia Plan ranging from 1971-1975. NEP was introduced as a mechanism to restructure socio-economic condition of multi-ethnic country badly affected by the infamous racial riot occurred in 1969. The paramount task of restructuring the socio-economic condition of the people through NEP required the government to transform the public sector, including the higher-education sector. Under NEP, ethnic quota admission policy is implemented in public universities whereby the enrolment of students into public universities is based on ethnicity the majority of who are Malays (Sharum, 1980; Morsidi, 2009; Kamogawa, 2003). The enactment of The Universities and University Colleges Act (UUCA) 1971 on the other hand empowers the Ministry of Education as the sole provider of higher learning institutions in the country (Chang Da, 2007). In this regard, the Malaysian government has a vital role to ensure the unique characteristic of developing higher education for achieving balanced economic under NEP.

The government has subsidized a total of ninety percent of public universities expenditure (MOHE, 2007) that enable these institutions to charge low fee admission for the students. The method of channeling the fund is through negotiation between the universities and the Ministry of Education; once agreed the fund will be transferred to public universities (Ahmad, 2012; Albrect \& Ziderman, 1992). Scholarship scheme on the other hand, have been given to students studying locally and abroad subject to academic excellence and strong co-curriculum activities (Mehmet \& Hoong, 1985). These two methods of funding higher education, namely; macro and micro, have contributed to the expansion of public universities and subsequently produced knowledgeable human capitals for the development of the country.

However, the economic crisis that occurred in the nineties is among the main factors that contributed to higher education funding reform (Foong, 2008; Tham, 2010). The crisis affected public spending on the government sectors including higher education sector which resulted in the reduction of expenditure allocated to the public universities and scholarships to the students. Public universities were unable to accommodate the high demand of school leavers pursuing tertiary education certificates in the global economic transition into k-economy (Kamogawa, 2003; Ho, 2008; Molly, 2005). The depreciation of the national currency coupled with the imposition of high admission fee for international student's enrolment into universities in US, UK and Australia had distracted the government and parents to send students to study abroad. It was reported that before the crisis around fifty thousand Malaysian students studying abroad especially in USA and UK were either sponsored financially by the Government or self-sponsored.

The method of funding higher learning institutions and students has changed dramatically in the late nineties through the liberalization of higher education and the establishment of educational loan scheme managed by National Higher Education Fund popularly known as PTPTN. The promulgation of PHEA in 1996 has changed tertiary education system in Malaysia into two main category; public and private. This vital policy change has dramatically increased the supply of higher education places and eased the burden of the government expenditure in developing the sector. The formation of PTPTN in 1997 on the other hand, offers educational loans for students studying at higher learning institutions with the condition that the program must be accredited by Malaysia Quality Assurance (MQA). These two new policies have contributed to the growth of students which recorded the highest number of one million in 2012 (MOHE, 2013).

Nevertheless, the sustainability of educational loan managed by PTPTN has become a debatable issue partly on economic factor and another on political factor. The economic factor relates to an increase of students enrolments couple with a huge number of defaulters as of 2007 only fifty percent of the borrowers repaid the loan ((Shafinar \& Serguieva, 2009; Shafinar et al., 2011; S. Benjamin et al., 2011: Elistina et al., 2006). According to Morshidi (2010), the implementation of higher education policy is also subjected to political debate especially in the post period of $12^{\text {th }}$ General Election in 2008. Currently, during the pre-election of $13^{\text {th }}$ General Election among the debatable issues were the abolishment of PTPTN and the establishment of free education at the level of tertiary education (Harian, 2013; Utusan Malaysia, 2013). 
The launching of National Higher Education Plan Beyond 2020 (NHEP) in 2007 is another strategic plan to develop higher education sector in Malaysia (Ahmad, 2012; Morsidi, 2010). NHEP outlines two main strategic plans; to transform higher education sector as a hub of higher education and to decrease public spending allocated to public universities. The transformation of higher education sector into a hub of higher education in the region is expected to generate revenue for the country through international students' admission charges (Mok, 2008, 2010, 2011; Morshidi, 2010; Tham, 2010). As of 2010 the number of international students' enrolment into Malaysian higher learning institutions stood at eighty thousands and the figure is expected to increase into two hundred thousand by 2020 (MOHE, 2012). Under NHEP, public fund expenditure allocated to public universities which currently covers ninety percent of public universities' expenditure will also be reduced to seventy percent in 2020. Public universities are given greater autonomy to cover another thirty percent of the expenditure through various income generating activities such as venturing into business activities, consultation and setting waqf fund for higher education purpose (Ahmad, 2012; Morsidi 2011).

Based on the previous discussions, the challenges in public funding of higher education in Malaysia can be divided into two main factors; internal and external. An influx of enrolments for tertiary education which subsequently increase the amount of educational loan, large number of loan defaulters, large number of public universities currently stand at twenty institutions nationwide, and, the high cost incurred for purchasing materials and equipment for teaching and learning as well as conducting research activities are identified as the main internal factors. Meanwhile, global economic uncertainty is considered to be the main factor that undermines the public fund directed into higher learning sector. Among the funding alternatives suggested for public universities to cover their expenses are venturing into business activities, consultation and the creation of waqf fund.

\section{Literature Review}

The study of cash waqf was done by several researchers in recently time. Murat Çizakça (1998) explains that historical evidence indicates that the real exiting potential lies in the cash waqf. The waqf system has provided throughout Islamic history all the essential services at no cost to the state and a successful modernization of the system implies a significant cut in government expenditure and all the associated benefits including downsizing the state sector and a reduction or elimination of riba. Cengiz Toraman et al. (n. d.), conclude that in a society where health, education and welfare were entirely financed by gifts and endowments, the cash waqf carried serious implications for the very survival of the Ottoman Empire.

Islahi (1992) stated that the internationalization of the voluntary institution of waqf is needed nowadays, by setting up a non-government Muslim foundation which should provide public goods on large scale and attempt to combat illiteracy, sickness and lack of technical know-how. Monzer Kahf (1998) explains the importance of waqf for socioeconomic development, which is consists of creating and developing a third sector distinct from the profit-motivated private sector and the authority-based public sector, and changing this third sector with the responsibility of performing a group of tasks whose nature will make them better achieved. This third sector assigned in education, health, social and environmental welfare. Furthermore, it can provide defense services and public utilities in many instances.

Chowdhury et al. (2011) explain that cash waqf would also help to reform the present institutional setup and their networking throughout the country with a view of increasing their performances. According to Muhammad Ridhwan Ab. Aziz (2012), waqf in education is not a new development in Islam. Looking at the history, it can be observed that since the beginning of Islam, in the early seventh century, many educational activities were financed by waqf and voluntary contributions. It is a historical fact that Muslim society depended considerably on waqf for the funding of education at all levels. For instance, it is reported that, under the Islamic rule, the island of Sicily had 300 elementary schools. All of them are built by waqf and all of them are provided with waqf revenues for payment of teachers and school supplies.

In fact, the provision of waqf for education is probably responsible for the usually common independent mentality noted in scholars that kept them away from being influenced and manipulated by certain quarters. This has contributed in enhancing the integrity of the scholars and academia as a whole and also contributed to reduce the socio-economic differences by offering education to those who can take it in merit basis, rather than on ability to pay educational services. Therefore, the economically poor people in the society will be assisted to reach the socioeconomic pathway faster. In order to advance in the educational field and revive the glory of the Muslim society, the International Islamic University Malaysia (IIUM) for instance, has established the IIUM Endowment Fund (IEF) since 1999 (Aziz, 2012).

Wafa (2010) explains that the impact of developing waqf for education in Malaysia not only promoting the significant rule of waqf towards the country, but also will (1) promote the third sector of Islamic economic, (2) 
establish economic activities through several projects, and business, (3) complement the government aid, benevolent and educational programs, and (4) promote the oneness of society.

In addition, Muhammad Ridhwan et al. (2013) explain about the waqf bank models that can be apply for Islamic waqf bank and also conclude that there is possible structure for waqf model and instrument that can be implemented in the future for the financing in education.

Other than that, Mohd Asyraf et al. (2013) conclude that there is strong willingness to contribute for waqf bank from any level of income despite the low income level as well the high income level. The only reasons that they did not want to contribute for Islamic waqf bank is lack of knowledge about waqf and lack of trust for the people who represent as an agent for Islamic waqf bank to collect waqf donation. Thus the study about waqf collection instrument has to be made in order to solve the problem. Also institute of higher learning have to provide reading material regarding waqf for public to understand the concept of waqf.

Moreover, Muhammad Ridhwan et al. (2013) stated that students will be more motivated if they get free education from Islamic waqf bank thus it will ease the burden of their parent. Islamic waqf bank is an alternative for education loan and a replacement for PTPTN. Also, there is high demand on the establishment of Islamic waqf bank among Muslim public and student.

\section{Method}

The research methodology used by the researchers is quantitative method. The method used throughout the research is through the questionnaires since the use of questionnaires allow us to get information in the most accurate manner. The questionnaires are randomly distributed among Muslim students in selected university in Selangor and Negeri Sembilan. Each questionnaire is distributed directly to each respondents amounting to 250 students. Random sampling is the purest manifestation of probability sampling. Every part of population has an equivalent chance of being chosen. At the point when there are huge populaces, it is difficult to distinguish each part of the populace, so the pool of accessible subjects gets to be predisposition.

The researcher would randomly choose assigned respondents from various related parties. After a thorough survey, data from respondents' answers are analyzed statistically through the use of SPSS version 20 . This study will analyze the frequency of each variable in the survey questions, since each respondent has their own evaluation on the issue, which is useful in this analysis. Results of the analysis will determine the level of assessment of each respondent on various aspects of this study. The reliability of the scale was tested using the Cronbach Alpha.

Table 1. The relief of higher education loan through Islamic Waqf bank

\begin{tabular}{ll}
\hline No & Item Cronbach Alpha $=0.670$ \\
\hline 1 & Source of Fund \\
2 & Exempted From Loan Repayment \\
3 & Islamic $W a q f$ Bank is an Alternative for Education Loan \\
\hline
\end{tabular}

\section{Discussion}

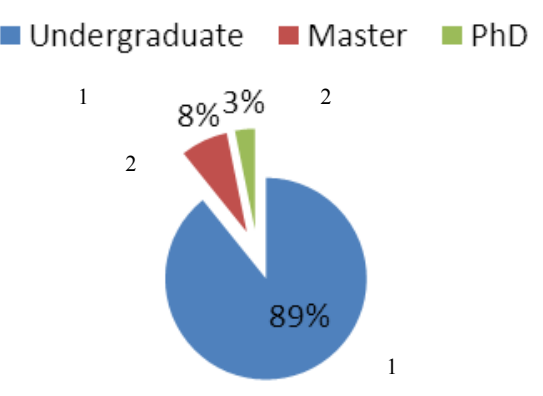

Figure 1. Students level of education 
The above pie chart shows the demography of the study. Three levels of education were taken into sample for the findings within the research. Three of them were undergraduates, Masters and $\mathrm{PhD}$ students. There are about three percent of $\mathrm{PhD}$ students, eight percent of Masters and eighty nine percent of undergraduates who were involved. These students were sampled from four different Universities in Selangor and Negeri Sembilan for this particular study.

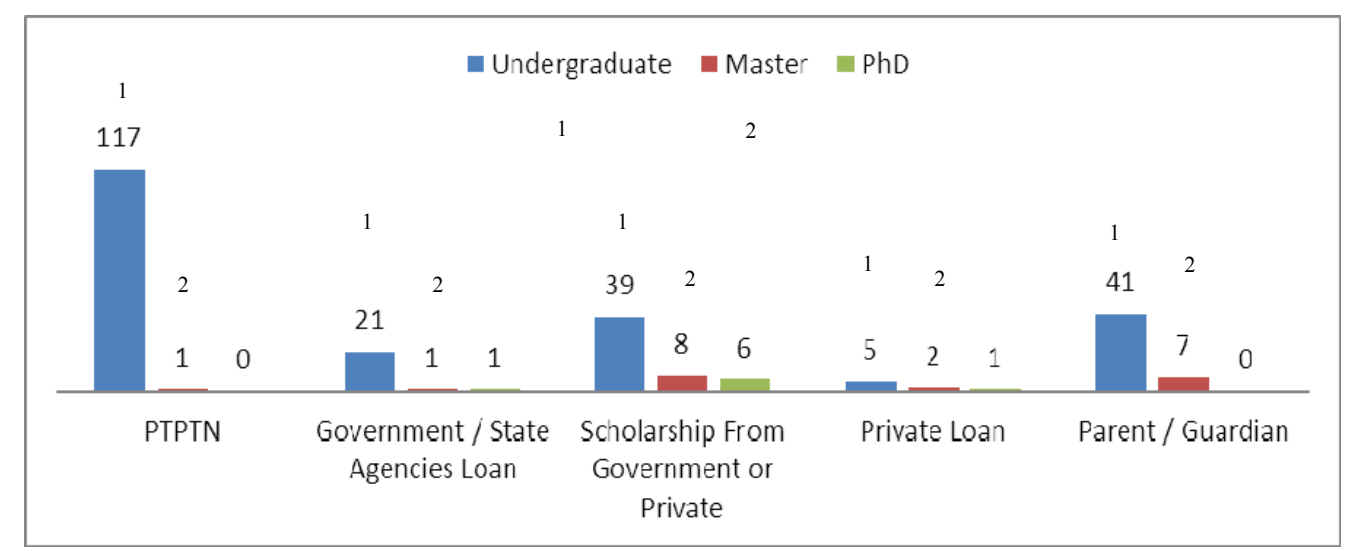

Figure 2. Source of fund

Figure 2 shows the source of funds for each level of study. There were 117 undergraduate students, 1 master student and none PhD student taking PTPTN as their source of funds. Next, there were 21 undergraduate, 1 master and $1 \mathrm{PhD}$ student taking government or state agencies loan. After that, there were 39 undergraduate, 8 masters and $6 \mathrm{PhD}$ students taking scholarship from government or private institution. Moreover, there were 5 undergraduate, 2 master and $1 \mathrm{PhD}$ students taking private loan as their source of funds for education. And lastly, there were 41 undergraduate, 7 master and none of $\mathrm{PhD}$ students who sponsored by their parents or guardians.

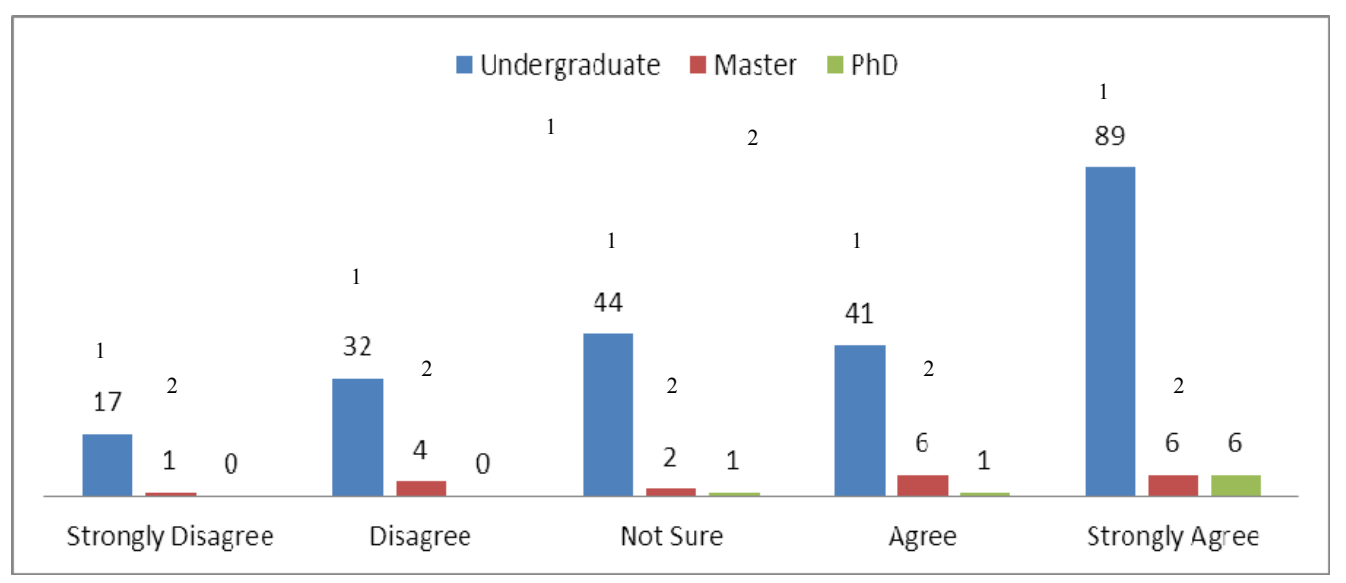

Figure 3. Exempted from loan repayment

Figure 3 shows the student's desire to waive for loan repayment. There were 17 undergraduates, 1 master and none of PhD students who strongly disagreed with the statement. There were 32 undergraduates, 4 masters and none of $\mathrm{PhD}$ disagreed with the same statement. Next, there were 44 undergraduates, 2 masters and $1 \mathrm{PhD}$ students not sure with this statement. After that, there were 41 undergraduates, 6 masters and $1 \mathrm{PhD}$ students were agreed with this statement. Lastly, there were 89 undergraduates, 6 masters and $6 \mathrm{PhD}$ strongly agreed with loan repayment exemption. In general, most of the respondents agreed that free education is the most possible method for furthering their studies. 


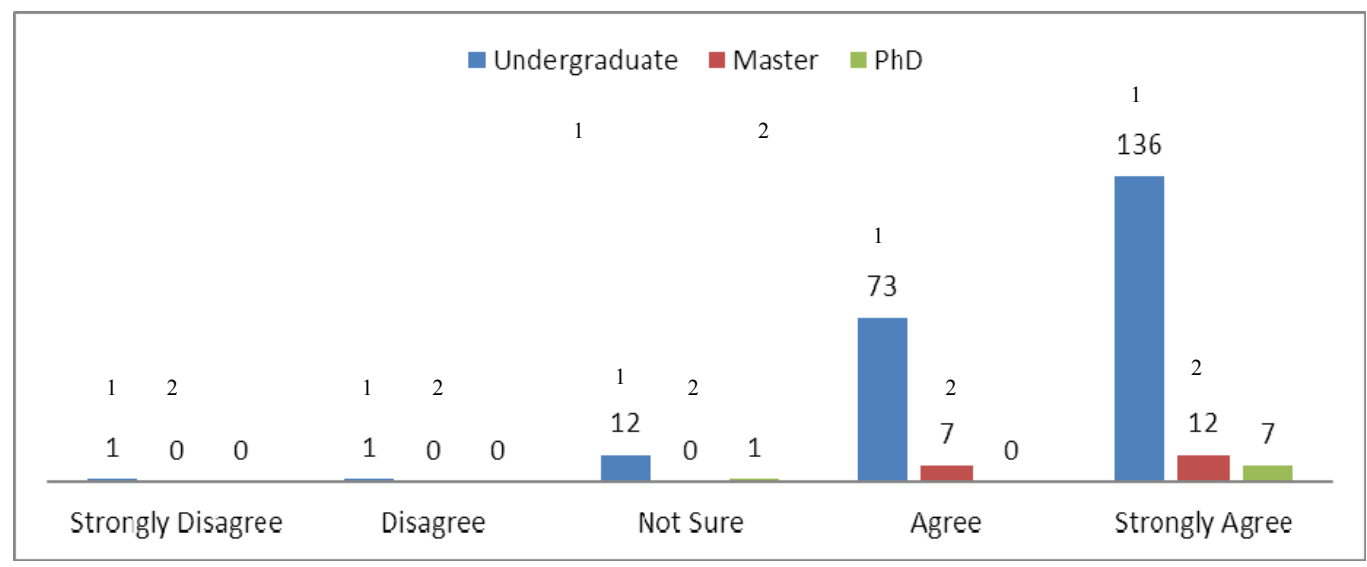

Figure 4. Islamic Waqf bank is an alternative for education loan

According to figure 4, the result shows 1 undergraduate student strongly disagreed, 1 undergraduate student disagreed, 12 undergraduate students were not sure, whereas 73 undergraduate students agreed and 136 undergraduate student that strongly agreed with the statement above. There were, no master student strongly disagreed, none of master student disagreed, none master student students were not sure, while 7 master students agreed and 12 master students that strongly agreed with the statement above. No PhD students strongly disagreed, none of $\mathrm{PhD}$ students disagreed, $1 \mathrm{PhD}$ students were not sure, none of $\mathrm{PhD}$ students agreed and 7 of them strongly agreed with the same statement. Therefore, most of the students agreed that there is a need for the establishment of Islamic waqf bank as an alternative for new financing mechanism for education.

\section{Conclusion and Suggestion}

To conclude, the establishment of Islamic waqf bank is timely as showed from the survey. The students are inclined to have Islamic waqf bank for their educations' financing. Islamic waqf bank as an alternative to loan is apparently the best solution for them. They will no longer have to worry about paying back the loan because of the huge commitments in the future. The majority of the undergraduate students took PTPTN as their source of education fund, while most Master and PhD students took scholarship from government or private institutions. Thus, the process of establishing Islamic waqf bank requires ample study in order to be a new alternative for educational financing and indeed a relief for most of the students.

\section{Acknowledgments}

This research is benefited from the funding of the Exploratory Research Grant Scheme (ERGS) of the Ministry of Education, Malaysia (The Establishment of Islamic Waqf Bank Model for Financing in Education: USIM/ERGS-FEM-33-50212).

\section{References}

Aziz, M. R. A. (2012). Introduction to Islamic Institutions in Economics and Finance. Bandar Baru Nilai: USIM Publisher.

Aziz, M. R. A. (2013). Islamic Banking and Finance in Malaysia: System, Issues and Challenges. Bandar Baru Nilai: USIM Publisher.

Aziz, M. R. A., \& Yusof, M. A. (2013). The Inclination of Student and Public Towards the Establishment of Islamic Waqf Bank. World Applied Science Journal, 26(1).

Chowdhury et al. (2011). Economics of Cash WAQF Management in Malaysia: A proposed Cash WAQF model for practitioners and future researchers. African Journal of Business Management, 5(30).

Çizakça, M. (1998). Awqaf in History and Its Implications for Modern Islamic Economies. Islamic Economic Studies, 6(1).

Islahi, A. A. (1992). Provision of Public Goods: Role of the Voluntary Sector (Waqf) In Islamic History. Financing Development In Islam: Seminar proceeding series IRTI \& IDB.

Jalil, A., \& Ramli, A. M. (2008). Waqf Instruments for Construction Contract: An Analysis of Structure. Journal of Muamalat and Islamic Finance, 5(1). 
Kahf, M. (1998). Financing the Development of Awqaf Property. Working Paper for the Seminar on Development of Awqaf by IRTI. Malaysia: Kuala Lumpur.

Laila, T. (n. d.). Innovations in Islamic Philanthropy and Monetization of Islamic Philanthropic Instruments. Bangladesh: Institute of Hazrat Mohammad Saw.

Mohammad MTSH. (2008). Sustaining The Means Of Sustainability: The Need For Accepting Wakaf (Waqf) Assets In Malaysian Property Market. The $14^{\text {th }}$ Annual Conference of the Pacific Rim Real Estate Society. Kuala Lumpur, Malaysia.

Mohammad, H., Sabit, M. T. B., Iman, B. H. M., \& Hamid, A. (2006). Obstacles of the Current Concept of Waqf to the Development of Waqf Properties and the Recommended Alternative. Malaysian Journal of Real Estate, 1(1).

Muslim, A. A. (2009). In A. Zahwah, \& A. 'Inayah (Eds.), Shahih Muslim. Lebanon: Daar al-Kutub al-“Araby.

Nunnaly, J. C. (1987). Psychological Theory (2nd ed.). New York: McGagraw-Hill.

Sabit, M. T., \& Haji, M. (2011). Towards an Islamic Social (Waqf) Bank. International Journal of Trade, Economics and Finance, 2(5).

Toraman et al. (n. d.). Cash Awqaf in the Ottomans as Philanthropic Foundations, and their Accounting Practices. Retrieved from http://journal.mufad.org

Wafa, S. M. G., \& Wafa, B. S. A. (2010). Development of waqfs for Education in Malaysia. Working paper presented on 7th International Conference-The Tawhidi Epistemology: Zakat and Waqf Economy. Bangi.

\section{Copyrights}

Copyright for this article is retained by the author(s), with first publication rights granted to the journal.

This is an open-access article distributed under the terms and conditions of the Creative Commons Attribution license (http://creativecommons.org/licenses/by/3.0/). 